\title{
A new chymotrypsin-like serine protease involved in dietary protein digestion in a primitive animal, Scorpio maurus: purification and biochemical characterization
}

\author{
Hanen Louati, Nacim Zouari, Nabil Miled and Youssef Gargouri*
}

\begin{abstract}
Background: Most recent works on chymotrypsins have been focused on marine animals and insects. However, no study was reported in chelicerate.

Results: Scorpion chymotrypsin-like protease (SCP) was purified to homogeneity from delipidated hepatopancreases. The protease $\mathrm{NH}_{2}$-terminal sequence exhibited more than $60 \%$ monoacids identity with those of insect putative peptidases. The protease displayed no sequence homology with classical proteases. From this point of view, the protease recalls the case of the scorpion lipase which displayed no sequence homology with known lipases. The scorpion amylase purified and characterized by our time, has an amino-acids sequence similar to those of mammalian amylases. The enzyme was characterized with respect its biochemical properties: it was active on a chymotrypsin substrate and had an apparent molecular mass of $25 \mathrm{kDa}$, like the classically known chymotrypsins. The dependence of the SCP activity and stability on $\mathrm{pH}$ and temperature was similar to that of mammalian chymotrypsin proteases. However, the SCP displayed a lower specific activity and a boarder pH activity range (from 6 to 9).
\end{abstract}

Conclusion: lower animal have a less evaluated digestive organ: a hepatopancreas, whereas, higher ones possess individualized pancreas and liver. A new chymotrypsin-like protease was purified for the first time from the scorpion hepatopancreas. Its biochemical characterization showed new features as compared to classical chymotrypsin-higher-animals proteases.

\section{Background}

Proteases, including trypsin and chymotrypsin, constitute one of the largest families of enzymes in the animal kingdom involved in dietary protein digestion [1]. Trypsin and trypsin-like proteases have received a great interest and were well characterized. However, informations about chymotrypsins are less available [2]. Chymotrypsins cleave the peptides on the carboxyl side of phenylalanine, tyrosine and tryptophan residues and have been purified and characterized from mammals $[3,4]$; fishes [5-7] and crustaceans such as scallop (Pecten maximus) [8] and shrimp (Penaus vannamei) [9].

\footnotetext{
* Correspondence: ytgargouri@yahoo.fr

Laboratoire de Biochimie et de Génie Enzymatique des Lipases, ENIS, Université de Sfax, route de Soukra 3038, BP 1173 Sfax-Tunisia
}

Chymotrypsins act primarily as an aid of digestion and as anti-inflammatory agent by preventing tissue damage and fibrin clots. Consequently, they were used for treating bacterial, viral, fungal, and parasitic infections in mammals. Chymotrypsins were shown to possess an anti-cell-cell adhesion activity [10]. Most recent works on chymotrypsins have been focused on marine animals, while studies on chymotrypsins from terrestrial arthropods are scare. Scorpion, one of the most ancient chelicerates, was chosen in this work as a model of a primitive animal to characterize the enzymes involved in dietary proteins digestion.

Scorpions have changed little since the Silurian (450 million years), and were considered as the oldest known terrestrial species. The food of scorpions is composed exclusively of a live arthropods, insects, myriapods. It was 
well known that scorpions could survive several weeks without food or water. The scorpion digestive glands, which represent our starting tissue in this work, occupy most of the space in the preabdomen and are conspicuous, clumped together and cannot be distinguished as separate glands. The scorpion digestive glands were studied at the ultrastructure level $[11,12]$. The digestive diverticula of scorpion were composed of two differentiated cells: basophilic cells and digestive cells. Whereas basophilic cells produce exoenzymes, digestive cells ensure intracellular digestion of nutrients absorbed by pinocytosis and store lipids, glycogen and mineral salts. The digestive mode of the scorpion associates a primitive intracellular process with an advanced extracellular one $[11,12]$. A lipase and an amylase were previously purified and characterized from digestive glands of the scorpion $[13,14]$. The scorpion digestive lipase was shown to possess new biochemical and structural properties in comparison to higher animals'digestive lipases. Furthermore, this enzyme was immunocytolocalized in the digestive cells and was thought to be persensible for an intracellular digestive process [12]. In contrast to what has been observed for scorpion lipase, the scorpion digestive amylase (SDA) was shown to share an $\mathrm{NH}_{2}$-terminal sequence similarity with pancreatic amylases. Despite the primitive character of the scorpion, similar biochemical properties have been observed between SDA and known pancreatic amylases. However, the absence of crossimmunoreactivity between porcine pancreatic amylase and anti-SDA serum strengthens the idea that SDA could be structurally different from mammalian pancreatic amylases [14].

To the best of our knowledge, no proteases from the scorpion digestive glands have been purified and characterized.

This paper reports, for the first time, the purification to homogeneity of an active chymotrypsin-like protease from the scorpion digestive glands. This protease was characterized with respect to its biochemical properties.

\section{Materials and methods Reagents}

Casein sodium salt from bovine milk, ethylenediaminetetraacetic acid (EDTA), phenylmethylsulfonyl fluoride (PMSF), dimethylsulfoxide (DMSO), dithio-bis-nitrobenzoic acid (DTNB), trichloroacetic acid (TCA), glycine, ammonium sulphate, $\beta$-mercaptoethanol, benzoyl-Arg$p$-nitroanilide (BAPNA), N-Succinyl-L-Ala-L-Ala-L-ProL-Phe-p-nitroanilide (SAPNA), N-alpha-(p-toluene sulfonyl)-L-arginine methyl ester (TAME), and protein markers for molecular masses 14,200-45,000 Da were purchased from Sigma Chemical Co. (USA). Tris (hydroxymethyl) aminomethane was procured from Panreac Quimica SA (Spain). Sodium dodecyl sulphate
(SDS), acrylamide, ammonium persulphate, N, N, N', $\mathrm{N}$-tetramethyl ethylenediamine (TEMED), and Coomassie Brilliant Blue R-250 were from Bio-Rad Laboratories (Mexico). DEAE-Sephadex, Sephadex G-100, Sephadex G-50 and SP-Sepharose were from Pharmacia Biotech (Sweden). All other reagents were of analytical grade.

\section{Proteins}

Pure porcine trypsin protease (PTP), pure bovine chymotrypsin protease (BCP) and bovine serum albumin (BSA) were purchased from Sigma Chemical Co. (USA).

\section{Determination of protein concentration}

Protein concentration was determined as described previously [15], using $\mathrm{BSA}\left(\mathrm{E}^{1 \%} \mathrm{~cm}=6.7\right)$ as reference.

\section{Animals}

Scorpions (chelicerate, scorpionidae, Scorpio maurus) were collected alive from the area of Agareb (Sfax, Tunisia) and frozen until death.

\section{Delipidation of scorpion hepatopancreases}

After defreezing, preabdomens were cleared from the cuticle and delipidated according to the method described previously [16]. After delipidation, $15 \mathrm{~g}$ of powder were obtained from $60 \mathrm{~g}$ of fresh tissue isolated from 200 scorpions.

\section{Proteolytic activities}

In order to ensure linear course of reaction, preliminary enzyme assays were performed in order to determine the concentration of substrate, the volume of crude enzyme extract and the time course of the reaction (data not shown). Protease activity was measured by the method of Kembhavi using casein as substrate [17]. Enzyme solution $(0.5 \mathrm{~mL})$ suitably diluted was mixed with $0.5 \mathrm{~mL}$ of $100 \mathrm{mM}$ Tris- $\mathrm{HCl} \mathrm{pH} \mathrm{9,} \mathrm{containing} 1 \%$ casein, and incubated for $10 \mathrm{~min}$ at $50^{\circ} \mathrm{C}$. The reaction was stopped by addition of $0.5 \mathrm{~mL}$ TCA $(20 \%$, w/v). The mixture was allowed to stand at room temperature for $15 \mathrm{~min}$ and then centrifuged at 13,000 rpm for 15 min to remove the precipitate. The absorbance was measured at $280 \mathrm{~nm}$. A standard curve was generated using solutions of $0-50 \mathrm{mg} / \mathrm{mL}$ tyrosine. One unit of protease activity was defined as the amount of enzyme, which liberated $1 \mu \mathrm{g}$ tyrosine in $1 \mathrm{~min}$ at $50^{\circ} \mathrm{C}$ and at $\mathrm{pH} 9$ for scorpion chymotrypsin-like protease (SCP) and at $\mathrm{pH} 7$ for porcine trypsin protease (PTP) and bovine chymotrypsin protease (BCP).

Chymotrypsin activity was determined using $20 \mu \mathrm{M}$ N-Succinyl-L-Ala-L-Ala-L-Pro-L-Phe-p-nitroanilide (SAPNA) in $10 \mathrm{mM} \mathrm{CaCl} 2,50 \mathrm{mM}$ Tris- $\mathrm{HCl}$ buffer, $\mathrm{pH}$ 7.5. Then, $20 \mu \mathrm{L}$ of the enzymatic extracts was added to $980 \mu \mathrm{L}$ of the substrate solution and, after incubation at 
$25^{\circ} \mathrm{C}$, the absorbance at $410 \mathrm{~nm}$ was recorded [18]. Chymotrypsin activity was expressed as $\mathrm{U} / \mathrm{mg}$. Values of different enzymatic activities are the means of three independent experiments.

Trypsin activity was determined using benzoyl-Arg- $p$ nitroanilide (BAPNA) as substrate [19]. BAPNA (1 mM) was dissolved in $1 \mathrm{~mL}$ of DMSO and then diluted to 100 $\mathrm{mL}$ with $10 \mathrm{mM} \mathrm{CaCl}_{2}, 50 \mathrm{mM}$ Tris- $\mathrm{HCl}$ buffer, $\mathrm{pH}$ 7.5. Then, $25 \mu \mathrm{L}$ of the enzymatic extracts were added to 1.25 $\mathrm{mL}$ of BAPNA at $25^{\circ} \mathrm{C}$ and the absorbance at $410 \mathrm{~nm}$ was recorded after $5 \mathrm{~min}$. Trypsin activity was expressed as $\mathrm{U} / \mathrm{mg}$, were $\mathrm{U}$ was to the amount of enzyme yielding 0.1 unit of absorbance per min.

Esterase activity of trypsin was determined using $\mathrm{N}$ alpha-(p-toluene sulfonyl)-L-arginine methyl ester (TAME) as the substrate on the basis of the method of Hummel with slight modifications [20]. The reaction mixture comprised $2.8 \mathrm{~mL}$ of the substrate $(1 \mathrm{mM}$ TAME in $0.05 \mathrm{M}$ Tris- $\mathrm{HCl}$ buffer, $\mathrm{pH} 8.5$ ) and $0.2 \mathrm{~mL}$ of the enzyme solution. The reaction mixture was thoroughly mixed, and the release of toluene sulfonyl arginine was measured at $247 \mathrm{~nm}$.

\section{Effect of protease inhibitors}

The effects of enzyme inhibitors on chymotrypsin activity were studied using phenylmethylsulfonyl fluoride (PMSF), thiol reagent dithio-bis-nitrobenzoic acid (DTNB), benzamidine, $\beta$-mercaptoethanol and ethylenediaminetetraacetic acid (EDTA). The purified enzyme was preincubated with inhibitors for $30 \mathrm{~min}$ at $25^{\circ} \mathrm{C}$ and then, the remaining enzyme activity was estimated using casein as a substrate. The enzyme activity measured in the absence of inhibitors was taken as $100 \%$.

\section{Purification steps of SCP}

Delipidated powder (10 g) of scorpion hepatopancreases was suspended in $100 \mathrm{~mL}$ of buffer A (10 mM Tris- $\mathrm{HCl}$ $\mathrm{pH} 8,10 \mathrm{mM} \mathrm{NaCl}$ and $\left.4 \mathrm{mM} \mathrm{CaCl}_{2}\right)$. The mixture was stirred during $30 \mathrm{~min}$ at $4^{\circ} \mathrm{C}$, then centrifuged for 30 $\min$ at $12,000 \mathrm{rpm}$.

- DEAE-Sephadex: The supernatant was loaded onto a DEAE-Sephadex column $(3 \times 20 \mathrm{~cm})$ equilibrated with buffer A. Under these conditions, the enzyme did not adsorb on the cationic support and was eluted during a washing step by the same buffer A. This step was important to eliminate many contaminants and to clarify the enzymatic solution (data not shown).

- Ammonium sulfate precipitation: The pooled fractions of DEAE-Sephadex column were subjected to ammonium sulfate precipitation. SCP precipitated in a saturation of $75 \%$ ammonium sulfate added under stirring conditions at $4^{\circ} \mathrm{C}$. After centrifugation (30 min at $12,000 \mathrm{rpm}$ ), the pellet was resuspended in $12 \mathrm{~mL}$ of buffer B (10 mM sodium acetate $\mathrm{pH}$ 6, $10 \mathrm{mM} \mathrm{NaCl}$ and $4 \mathrm{mM} \mathrm{CaCl}_{2}$ ). Insoluble material was removed by centrifugation for $5 \mathrm{~min}$ at 12,000 rpm.

- Filtration on Sephadex G-100: The supernatant issued from ammonium sulfate precipitation, was loaded on a gel filtration Sephadex G-100 column (3.2 $\times 100 \mathrm{~cm}$ ) equilibrated with buffer B. Elution of protease was performed with the same buffer at $30 \mathrm{~mL} / \mathrm{h}$. The fractions containing the protease activity (eluted at 1.4 void volume) were pooled (fractions from 58 to 98) (Figure 1A).

- FPLC Anion exchange SP-Sepharose: The pooled fractions of Sephadex G-100 column were concentrated and injected onto an FPLC SP-Sepharose column equilibrated with buffer B. The column $(1.6 \times 15 \mathrm{~cm})$ was rinsed with the same buffer. Then, proteins were eluted with a linear gradient of $\mathrm{NaCl}$ prepared in buffer B. SCP was eluted at a salt concentration of $40-80 \mathrm{mM} \mathrm{NaCl}$ (Figure 1B).

- Filtration on Sephadex G-50: Active fractions eluted from SP-Sepharose column were pooled and loaded onto a gel filtration Sephadex G-50 column $(3 \times$ $90 \mathrm{~cm}$ ) equilibrated with buffer A. Elution of protease was performed with the same buffer at $30 \mathrm{~mL} / \mathrm{h}$. The fractions containing the protease activity (eluted at 1.2 void volume) (Figure 1C) (fractions from 75 to 105) were analysed by SDS-PAGE, native-PAGE and by zymography (Figure 2A and $2 \mathrm{~B}$ ).

\section{SDS-PAGE, native-PAGE and zymography}

Analytical polyacrylamide gel electrophoresis of proteins in the presence of SDS-PAGE was performed as described by Laemmli [21]. Native PAGE was performed according to the procedure of Laemmli [21], except that the sample was not heated and SDS and reducing agent were left out. Casein-zymography was performed on native-PAGE according to the method of Garcia-Carreno [19]. Samples were mixed with electrophoresis loading buffer and electrophoresed on a native PAGE. After electrophoresis, the gel was submerged in $100 \mathrm{~mL}$ of $1 \%(\mathrm{w} / \mathrm{v})$ casein in $100 \mathrm{mM}$ Tris- $\mathrm{HCl}(\mathrm{pH} 8.0)$ for 30 $\min$ at $4{ }^{\circ} \mathrm{C}$ to allow the substrate to penetrate into the gel and then incubated for $45 \mathrm{~min}$ at $37^{\circ} \mathrm{C}$ in enzyme assay buffer (100 mM Tris- $\mathrm{HCl} \mathrm{pH} \mathrm{8.0)} \mathrm{for} \mathrm{the} \mathrm{develop-}$ ment of enzyme activity bands. After washing, the gel was stained with Coomassie Brilliant Blue R-250. Development of a clear zone on the blue background indicated the presence of protease activity.

\section{Amino acid sequencing}

The $\mathrm{NH}_{2}$-terminal end of SCP was sequenced by automated Edman's degradation, using an Applied Biosystems Protein Sequencer Procise 492 cLC [22]. 


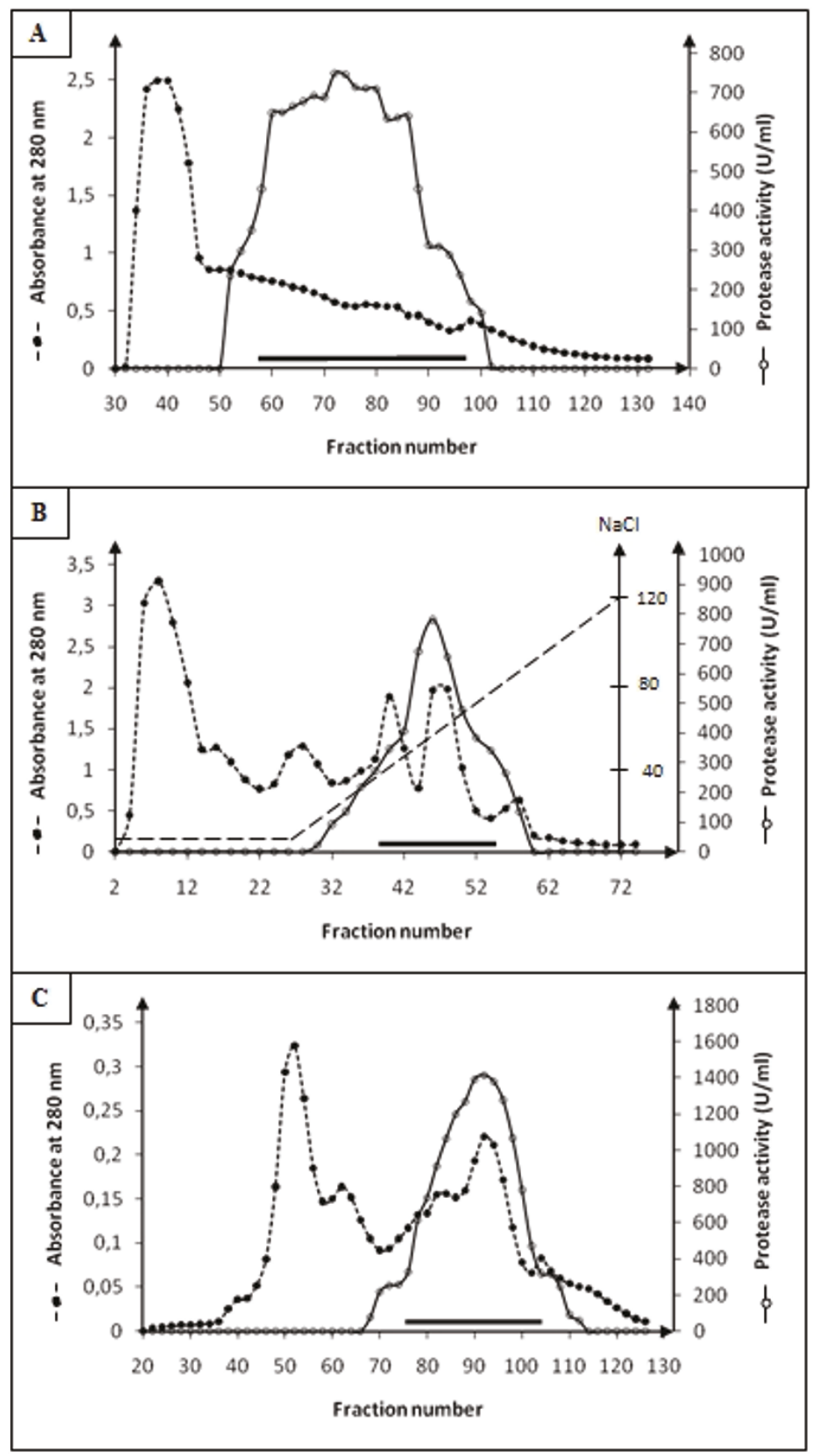

Figure 1 Chromatography of SCP on Sephadex G-100 and FPLC SP-Sepharose. (A) Chromatography of SCP on Sephadex G-100. The column $(3.2 \times 100 \mathrm{~cm})$ was equilibrated with buffer $\mathrm{A}(10 \mathrm{mM}$ acetate $\mathrm{pH} 6,10 \mathrm{mM} \mathrm{NaCl}$ and $4 \mathrm{mM} \mathrm{CaCl})$. The elution of protease was performed with the same buffer at a rate of $30 \mathrm{~mL} / \mathrm{h}$ and $5.6 \mathrm{~mL}$ by fraction. (B) Chromatography of SCP on FPLC SP-Sepharose. The column was equilibrated with buffer $\mathrm{A}(10 \mathrm{mM}$ Tris- $\mathrm{HCl} \mathrm{pH} 8,10 \mathrm{mM} \mathrm{NaCl}$ and $4 \mathrm{mM} \mathrm{CaCl}$ ); a linear gradient was applied from 10 to $120 \mathrm{mM} \mathrm{NaCl}$ in buffer B; the elution of protease was performed with the same buffer at a rate of $2 \mathrm{~mL} / \mathrm{min}$ and $3 \mathrm{~mL}$ by fraction. C: Chromatography of SCP on Sephadex G-50. The column $(3 \times 90 \mathrm{~cm})$ was equilibrated with buffer A. The elution of protease was performed with the same buffer at a rate of $30 \mathrm{~mL} / \mathrm{h}$ and $4.8 \mathrm{~mL}$ by fraction. SCP activity was measured as described in materials and methods section using casein as substrate. SCP activity was measured as described in materials and methods section using casein as substrate. 


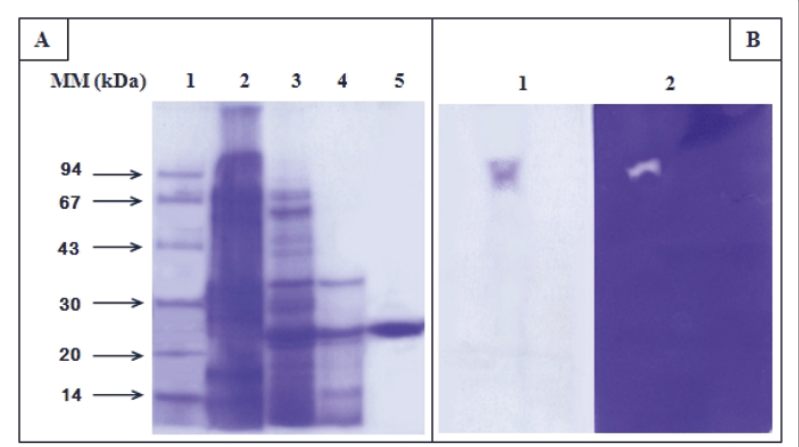

Figure 2 SDS-PAGE and Native-PAGE of the SCP. (A) Analysis of purified SCP by SDS-PAGE (13\%). Lane 1, molecular mass markers (Pharmacia); lane 2, SCP solution (300 $\mu \mathrm{g}$ ) obtained after DEAESephadex chromatography; lane 3, SCP solution $(60 \mu \mathrm{g})$ obtained after Sephadex G-100 chromatography; lane 4, SCP solution (40 $\mu \mathrm{g})$ obtained after SP-Sepharose chromatography; lane 5, purified SCP obtained after Sephadex G-50 chromatography $(20 \mu \mathrm{g})$. The gel was stained with Coomassie blue. (B) Native-PAGE of the purified enzyme, protein stained by Coomassie blue (lane 1); zymogram of the purified chymotrypsin SCP (lane 2).

\section{Results and discussion}

Purification of the scorpion protease and general characteristics

A protease was purified from the digestive glands of the scorpion. The purification procedure includes an ammonium sulfate precipitation and chromatographic steps (Table 1). After the last step of Sephadex G-50 chromatography, the purification factor reached 315 with a recovery yield of $45 \%$ of the initial protease activity. At this stage, the protease specific activity was found to be $75000 \mathrm{U} / \mathrm{mg}$ using casein as substrate at $50^{\circ} \mathrm{C}$ and at $\mathrm{pH}$ 9. The purified enzyme appears as one homogenous band having an apparent molecular mass of $25 \mathrm{kDa}$ (Figure 2A). The molecular mass of scorpion protease was similar to those reported for mammalian and insect chymotrypsin proteinases (22-30 kDa) [23-26]. Furthermore, the zymogram of the purified enzyme under native conditions displayed a protease activity.

The $\mathrm{NH}_{2}$-terminal sequencing of the purified protease allowed the identification of 29 residues: VEFGRYFRLSEINQFLESLAVTYPEHVI (Table 2). Using the $\mathrm{NH}_{2}$ terminal 29 residues, we run a blast against peptidase

Table 1 Flow sheet of scorpion chymotrypsin-like protease purification.

\begin{tabular}{|c|c|c|c|c|c|}
\hline Purification step & $\begin{array}{c}\text { Total activity* (U) } \\
\times 10^{3}\end{array}$ & Protein $(\mathrm{mg})$ & $\begin{array}{c}\text { Specific activity } \\
(\mathrm{U} / \mathrm{mg})\end{array}$ & $\begin{array}{c}\text { Activity recovery } \\
\text { (\%) }\end{array}$ & $\begin{array}{c}\text { Purification } \\
\text { factor }\end{array}$ \\
\hline $\begin{array}{l}\text { Extract of SCP } \\
(\mathrm{pH} 8)\end{array}$ & $220 \pm 47$ & $925.80 \pm 4.68$ & $237.60 \pm 8.90$ & 100 & 1 \\
\hline DEAE-Sephadex & $179.25 \pm 12$ & $203.95 \pm 5.90$ & $878.90 \pm 25.60$ & $81 \pm 5.70$ & $3.70 \pm 0.12$ \\
\hline $\begin{array}{l}\left(\mathrm{NH}_{4}\right)_{2} \mathrm{SO}_{4} \\
\text { Precipitation (75\%) }\end{array}$ & $164.80 \pm 8.90$ & $87 \pm 3.78$ & $1894.20 \pm 98.70$ & $91.90 \pm 3.70$ & $7.97 \pm 0.43$ \\
\hline $\begin{array}{l}\text { Sephadex G-100 } \\
\text { chromatography }\end{array}$ & $103.90 \pm 5.40$ & $15.80 \pm 0.87$ & $6575.90 \pm 578$ & $63 \pm 4.06$ & $27.67 \pm 0.28$ \\
\hline SP-Sepharose chromatography & $58.23 \pm 1.09$ & $0.98 \pm 0.23$ & $59418 \pm 320$ & $56 \pm 0.95$ & $250 \pm 2.70$ \\
\hline Sephadex G-50 chromatography & $26.25 \pm 1.25$ & $0.35 \pm 0.12$ & $75000 \pm 540$ & $45 \pm 1.05$ & $315.60 \pm 6.90$ \\
\hline
\end{tabular}

* One unit of protease activity was defined as the amount of enzyme, which liberated $1 \mu \mathrm{g}$ tyrosine in $1 \mathrm{~min}$ at $50^{\circ} \mathrm{C}$ and at $\mathrm{pH} 9$.

Table 2 Alignment of the $\mathrm{NH}_{2}$-terminal sequence of scorpion chymotrypsin-like protease with putative peptidases from Drosophila yakuba (MER142281), Drosophila erecta (MER144486), Drosophila simulans (MER136917), Trichoplusia ni (MER079404), Tribolium castaneum (MER169092) and Anopheles gambiae (MER021291) found in the MEROPS Database at http://merops.sanger.ac.uk/cgi-bin/blast/submitblast/merops/advanced.

\begin{tabular}{lcc}
\hline Potease origin & Access number & NH $_{\mathbf{2}}$-Terminal sequence \\
\hline Scorpio maurus & This study & VEFGRYFRLSEINQFLESLAVTYPEHVI \\
Drosophila yakuba & MER142281 & -RYYSHEEINQFIEDLAVKYPRRV- \\
Drosophila erecta & MER144486 & -RYYSHEEINQFIEDLARKYPQRV- \\
Drosophila simulans & MER136917 & -RYYNHEEINQFIEDLAREHP- \\
Trichoplusia ni & MER079404 & IGFETYYRHDEINDYLDELAATYPDLV- \\
Tribolium castaneum & MER169092 & IAFDHYLRHSEINNYLDQLAQNYPNIV- \\
Anopheles gambiae & MER021291 & 48\% \\
\hline
\end{tabular}

Residues in bold indicate the identical amino acids. 
Table 3 Specific activity of scorpion protease $(\mathrm{U} / \mathrm{mg})$ measured on various substrates.

\begin{tabular}{lllll}
\hline Substrate & TAME $^{\mathbf{a}}$ & BAPNA $^{\mathbf{b}}$ & SAPNA $^{\mathbf{c}}$ & Casein \\
\hline Scorpion protease & $<0.001$ & $0.01 \pm 0.002$ & $35 \pm 0.65$ & $75000 \pm 5400$ \\
Bovine chymotrypsin protease & nd & nd & $280 \pm 1.34$ & $197080 \pm 8750$ \\
Porcine trypsin protease & $1.3 \pm 0.12$ & $4.5 \pm 0.4$ & nd & $59125 \pm 4800$ \\
\hline
\end{tabular}

Bovine chymotrypsin (BCP) and porcine trypsin (PTP) were taken as positive standards for comparative purposes.

Data are expressed as means \pm SD of three determinations.

${ }^{a}$ TAME: N alpha-(p-toluene sulfonyl)-L-arginine methyl ester; ${ }^{b}$ BAPNA: benzoyl-Arginine- $p$-nitroanilide; ${ }^{c}$ SAPNA: N-Succinyl-L-Ala-L-Ala-L-Pro-L-Phe-p-nitroanilide; nd: not determined.

families found in the MEROPS database at http://merops. sanger.ac.uk/cgi-bin/blast/submitblast/merops/advanced.

The scorpion protease displayed a sequence similarity with putative proteases from various insects such as Drosophila, Trichoplusia, Tribolium and Anopheles (40$60 \%$ ) (Table 2). No similarity was found with classical chymotrypsin and trypsin proteases. Similar results were found with scorpion digestive lipase which $\mathrm{NH}_{2}$-terminal sequence shares an homology only with insects' putative lipases [13].

Proteases can be classified into various groups based on their mode of action. In order to determine the group of the scorpion protease, the enzyme activity was measured on different synthetic substrates: $\mathrm{N}$-alpha-(ptoluene sulfonyl)-L-arginine methyl ester (TAME) and benzoyl-Arg-p-nitroanilide (BAPNA) which are specific of trypsin proteases and N-Succinyl-L-Ala-L-Ala-L-ProL-Phe-p-nitroanilide (SAPNA), a specific substrate for chymotrypsin proteases (Table 3). Scorpion protease displayed no activity against trypsin substrates indicating that scorpion protease does not belong to the trypsin group. Interestingly, scorpion protease had a relatively high activity on chymotrypsin substrate (SAPNA). Based on its activity on SAPNA, the scorpion protease can be considered as a chymotrypin-like protease despite the absence of $\mathrm{NH}_{2}$-terminal sequence homology with classical chymotrypsins. The purified protease was therefore named Scorpion Chymotrypsin-like Protease (SCP).

\section{Characterization of SCP}

Effects of temperature on protease activity and stability

The effect of the temperature on SCP or bovine chymotrypsin protease (BCP) (taken as a model) activity and stability was checked (Figure 3). The SCP activity increased with the temperature to reach an optimum at $50^{\circ} \mathrm{C}$ then decreased sharply at higher temperatures (Figure 3A). One can say that SCP is thermoactive which is similar to that of mammalian and fish proteases $[6,27,2]$. SCP was stable until $40^{\circ} \mathrm{C}$ and lost its activity after $15 \mathrm{~min}$ of incubation at $50^{\circ} \mathrm{C}$ (Figure 3B). The fact that the enzyme was not stable but fully active at $50^{\circ} \mathrm{C}$ might explained by the substrate protection effect previously reported for other enzymes [28-30]. Similar results were obtained for BCP (Figure 3A).

\section{Effect of $\mathrm{pH}$ on protease activity and stability}

The effect of $\mathrm{pH}$ on the activity and the stability of the purified SCP was also examined and compared to that on BCP. Interestingly, the profile of the activity dependency of the activity on $\mathrm{pH}$ was different for SCP and $\mathrm{BCP}$. The SCP displayed a board $\mathrm{pH}$ range of activity (from 6 to 9). However, BCP showed a maximal activity at $\mathrm{pH} 7$ (Figure 4A). Both SCP and BCP were stable in a $\mathrm{pH}$ range of 6-11 (Figure 4B). The SCP was fully active at $\mathrm{pH} 9$ as was found for chymotrypsin-like
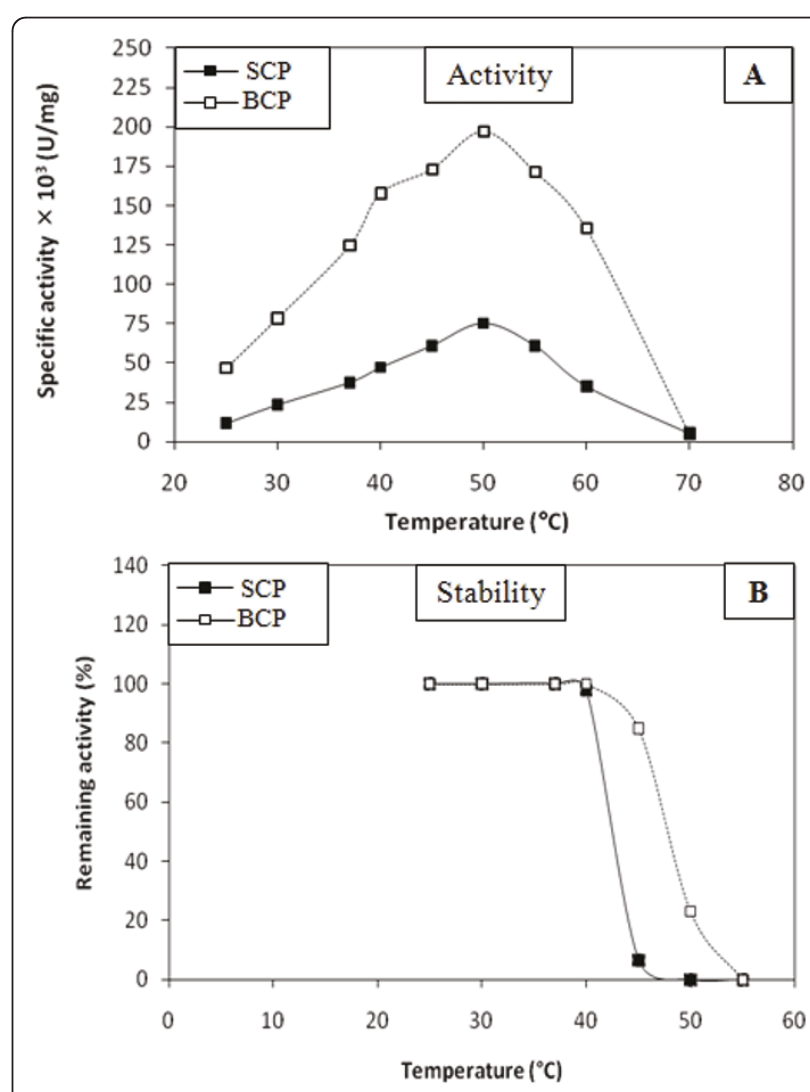

Figure 3 Effects of temperature. (A) Effects of temperature on SCP and BCP activities. (B) Effects of temperature on SCP and BCP stabilities. Enzyme activity was tested at various temperatures using casein as substrate at $\mathrm{pH} 9$ for the SCP and at $\mathrm{pH} 7.5$ for the BCP in the presence of $4 \mathrm{mM} \mathrm{CaCl}$. Residual enzyme activity was determined after $15 \mathrm{~min}$ in incubation and the initial activity before incubation was taken as 100\%. 


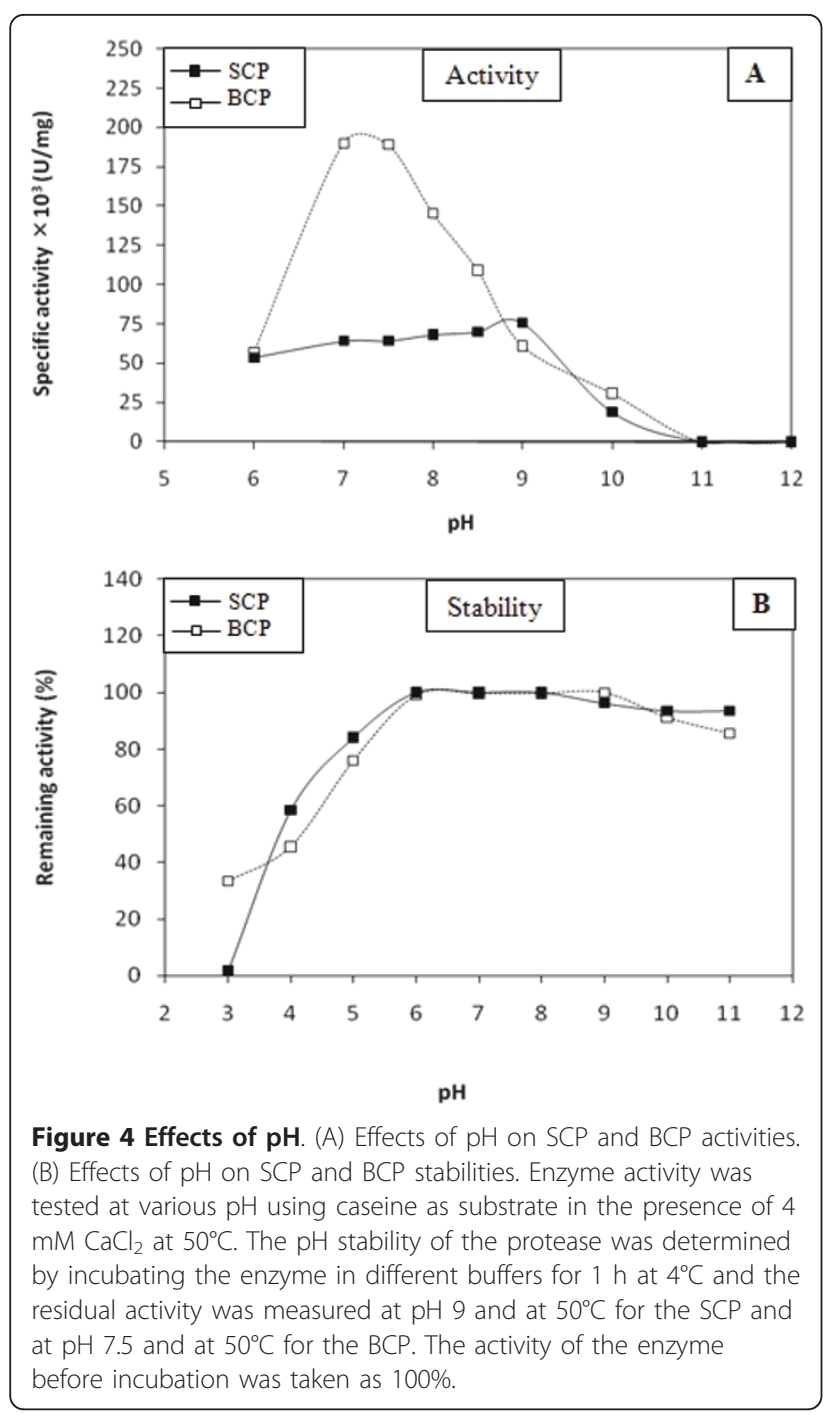

Table 4 Effect of inhibitors on scorpion chymotrypsin-like protease activity

\begin{tabular}{lcc}
\hline Inhibitors & Concentration (mM) & Residual activity (\%) \\
\hline None & 1 & 100 \\
\hline PMSF & 5 & 18 \\
& 1 & 7 \\
\hline DTNB & 5 & 100 \\
& 1 & 100 \\
\hline EDTA & 5 & 98 \\
& 10 & 60
\end{tabular}

Enzyme activity measured in the absence of any inhibitor was taken as $100 \%$. The remaining protease activity was measured after incubation of enzyme with each inhibitor at $4^{\circ} \mathrm{C}$ for $15 \mathrm{~min}$.

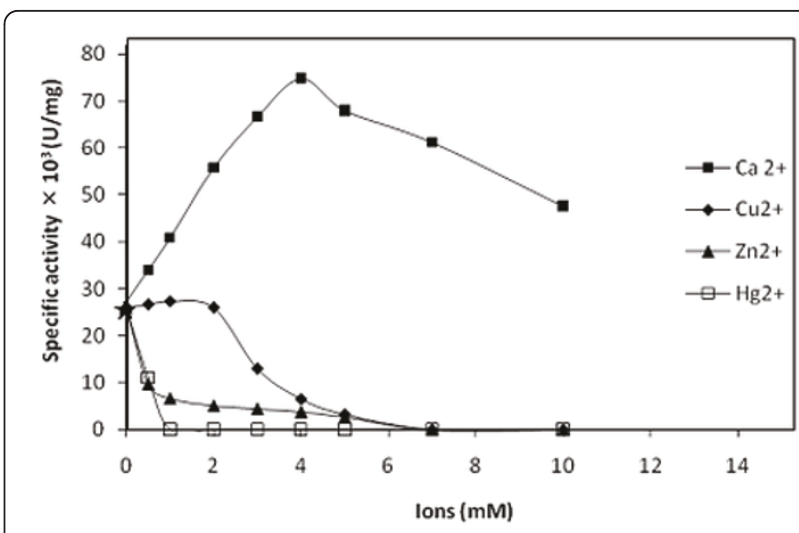

Figure 5 Effect of ions. Effect of increasing $\mathrm{Ca}^{2+}$ (black square), $\mathrm{Cu}^{2+}$ (black diamond), $\mathrm{Zn}^{2+}$ (black triangle) and $\mathrm{Hg}^{2+}$ (white square) ions concentrations on the SCP activity using casein as substrate; the star symbol indicates the value of protease activity measured in presence of $10 \mathrm{mM}$ EDTA. SCP activity was measured at $50^{\circ} \mathrm{C}$ and at $\mathrm{pH} 9$.

proteases from scallop (Pecten maximus) [8] and yellow mealworm (Tenebrio molitor) [31].

Effect of proteinase inhibitors and metal ions

The effect of various proteinase inhibitors (Table 4) and metal ions (Figure 5) on the SCP activity was studied. The SCP was strongly inhibited by PMSF, a serine protease inhibitor but not affected by cystein protease inhibitor (DTNB). Furthermore, EDTA which is a metalloprotease inhibitor, showed slight inhibitory effect on SCP (Table 4). These results strongly support that the purified enzyme is a serine protease. Similar inhibition patterns were reported for chymotrypsin-like proteases from scallop [8], lepidopteran insect Spodoptera exigua [32] and yellow mealworm [31]. The enzyme incubated with EDTA lost $60 \%$ of its initial activity (Figure 5). Only the addition of $\mathrm{Ca}^{2+}$ ions $(4 \mathrm{mM})$ enhanced the SCP activity which reaches its maximal specific activity $(75000 \mathrm{U} / \mathrm{mg})$. Nevertheless, $\mathrm{Hg}^{2+}, \mathrm{Zn}^{2+}$ or $\mathrm{Cu}^{2+}$ inhibited the SCP activity (Figure 5).

\section{Abbreviations}

$B C P$ : bovine chymotrypsin protease; BAPNA: benzoyl-Arg-p-nitroanilide; BSA: bovine serum albumine; DMSO: dimethylsulfoxide; DTNB: 5,5'-dithiobis (2nitrobenzoic acid); EDTA: ethylenediaminetetraacetic acid; FPLC: fast protein liquid chromatography; HPLC: high presure liquid chromatography; $\mathrm{kDa}$ : kilodalton; SCP: scorpion chymotrypsin-like protease; SAPNA: N-Succinyl-LAla-L-Ala-L-Pro-L-Phe-p-nitroanilide; SDA: scorpion digestive amylase; SDSPAGE: sodium dodecyl sulfate polyacrylamide gel electrophoresis; TAME: Nalpha-(p-toluene sulfonyl)-L-arginine methyl ester; TEMED: N, N, N', N'tetramethyl-ethylenediamine; TCA: trichloroacetic acid; PMSF: phenylmethanesulfonyl fluoride; PTP: porcine trypsin protease.

\section{Acknowledgements}

We are very grateful to Dr. Ali Bougatef (LGEM, Tunisia) for this precious help and for the fruitful discussions we had during the preparation of this manuscript. Special thanks to Pr. Hafeth Mejdoub (FSS, Tunisia) for the 
sequencing of the NH2-terminal of SCP. We are grateful to Hayet Ben Khaled (LGEM, Tunisia) for this fruitful discussion, kind help and for technical assistance during the preparation of this work. This work is part of a doctoral thesis by Hanen LOUATI. This work received financial support from Ministère de l'Enseignement Superieur et de la Recherche Scientifique, Tunisie.

\section{Authors' contributions}

$\mathrm{HL}$ carried out all the studies, analyzed the data and drafted the manuscript. NZ helped with the analysis of the data. NM helped with the discussion of the data and the correction of the manuscript. YG participated in the study design and helped to draft the manuscript. All authors have read and approved the final manuscript.

\section{Competing interests}

The authors declare that they have no competing interests.

Received: 11 March 2011 Accepted: 21 July 2011

Published: 21 July 2011

\section{References}

1. Tidwell DK, Bomba AK: Attitudes of people with celiac diseasetowards dietitians and medical nutrition therapy. J Am Diet Assoc 2001, 101:A-29.

2. Feng Y, Wen-Jin S, Bao-Ju L, Tao W, Le-Chang S, Kenji H, Min-Jie C: Purification and characterization of chymotrypsins from the hepatopancreas of crucian carp (Carassius auratus). Food Chem 2009, 116:860-866.

3. Guyonnet, Tuscik F, Long LP, Polanowski A, Travis J: Purification and partial characterization of the pancreatic proteolytic enzymes trypsin chymotrypsin and elastase from the chicken. J Chromatogr A 1999, 852:217-725.

4. Boeris V, Romanini D, Farruggia B, Pico G: Purification of chymotrypsin from bovine pancreas using precipitation with a strong anionic polyelectrolyte. Process Biochem 2009, 44:588-592.

5. Cohen T, Gertler A, Birk Y: Pancreatic proteolytic enzymes from carp (Cyprinus carpio): Purification and physical properties of trypsin, chymotrypsin, elastase and carboxipeptidase B. Comp Biochem Phys B 1981, 69:639-646.

6. Asgeirsson B, Bjarnason JB: Structural and kinetic propertises of chymotrypsin from Atlantic cod (Gadus morhua). Comparison with bovine chymotrypsin. Comp Biochem Phys B 1991, 99:327-335.

7. Castillo-Yanez FJ, Pacheco-Aguilar R, Garcia-Carreno FL, Navarrete-Del Toro MA, Felix Lopez M: Purification and biochemical characterization of chymotrypsin from the viscera of Monterey sardine (Sardinops sagax caeruleus). Food Chem 2006, 99:252-259.

8. Le Chevalier P, Sellos D, Van Wormhoudt A: Purification and partial characterization of chymotrypsin-like proteases from the digestive gland of the scallop Pecten maximus. Comp Biochem Phys B 1995, 110:777-784.

9. Fernandez Gimeneza AV, Garcia-Carreno FL, Navarrete del Torob MA, Fenuccia JL: Digestive proteinases of red shrimp Pleoticus muelleri Decapoda, Penaeoidea: partial characterization and relationship with molting. Comp Biochem Phys B 2001, 130:331-338.

10. Xiu-Zhen S, Xiao-Fan Z, Jin-Xing W: Molecular cloning and expression analysis of chymotrypsin-like serine protease from the Chinese shrimp, Fenneropenaeus chinensis. Fish Shellfish Immun 2008, 25:589-597.

11. Goyffon M, Martoja R: Cytophysiological aspects of digestion and storage in the liver of a scorpion. Cell Tissue Res 1983, 228:661.

12. Zouari N, Bernadac A, Miled N, Rebai T, De Caro A, Rouis S, Carriere F, Gargouri Y: Immunocytochemical localization of scorpion digestive lipase. Biochim Bioph 2006, 1360-1386.

13. Zouari N, Miled N, Cherif S, Mejdoub H, Gargouri Y: Purification and characterization of a novel lipase from the digestive glands of a primitive animal: the scorpion. Biochim Bioph Acta 2005, 1726.

14. Louati H, Zouari N, Fendri A, Gargouri Y: Digestive amylase of a primitive animal, the scorpion: Purification and biochemical characterization. Chromatogr B 2010, 878:853-860.

15. Bradford MM: A rapid and sensitive method for the quantitation ofquantities of protein utilising the principle of protein-drye binding. Anal Biochem 1976, 72:248.

16. Verger R, De Hass GH, Sarda L, Desnuelle P: Purification from porcine pancreas of two molecular species with lipase activity. Biochim Bioph Acta 1969, 188:272.
17. Kembhavi AA, Kulharni A, Pant AA: Salt-tolerant and thermostable alkaline protease from Bacillus subtilis NCIM No. 64. Appl Biochem Biotechnol 1993, 38:83-92.

18. Del Mar EG, Brodrick JW, Geokas MC, Largman C: Effect of oxidation of methionine in a peptide substrate for human elastases: A model for inactivation of $\boldsymbol{a}_{1}$-protease inhibitor. Biochem Biophys Res Co 1979, 88:346-350.

19. Garcia-Carreno FL, Dimes LE, Haard NF: Substrate-gel electrophoresis for composition and molecular weight of proteinases or proteinaceous proteinases inhibitors. Analytical Biochemistry 1993, 214:65-69.

20. Hummel BC, Schor JM, Buck FF, Boggiano E, De Renzo EC: Quantitative enzymic assay of human plasminogen and plasmin with azocasein as substrate. Anal Biochem 1965, 11:532-547.

21. Laemmli UK: Cleavage of structural protein during the assembly of the head of bacteriophage T4. Nature 1970, 227:680.

22. Hewik RM, Hunkapiller MW, Hood LE, Dreyer WJ: A gas liquid solid phase peptide and protein sequenator. Biol Chem 1981, 256:7990-7997.

23. Terra WR, Ferreira C: Insect digestive enzymes: properties, compartmentalization and function. Comp Biochem Phys 1994, 109:61-62.

24. Terra WR, Ferreira C, Jordao BP, Dillon RJ: Digestive enzymes.Edited by: Lehane MJ, Billingsley PF. Biology of the Insect Midgut, Chapman and Hall, London; 1996:153-194.

25. Lee MJ, Anstee JH: Endoproteases from the midgut of larval Spodoptera littoralis include a chymotrypsin-like enzyme with an extended binding site. Insect Biochem Mol Biol 1995, 25:49-61.

26. Graf L, Szilagyi L, Venekei I: Chymotrypsin.Edited by: Barrett AJ, Rawlings ND, Woessner JF. Handbook of Proteolytic Enzymes, Academic Press, San Diego; 1998:30-38.

27. Heu MS, Kim HR, Pyeun JH: Comparison of trypsin and chymotrypsin from the viscera of anchovy, Engraulis japonica. Comparative Biochemistry and Physiology 1995, 112:557-567.

28. Verger R: Pancreatic lipases. In Lipase. Edited by: Borgstrôm B, Brockman HL. Elsevier, Amsterdam; 1984:121-150.

29. Cherif S, Fendri A, Miled N, Trabelsi H, Mejdoub H, Gargouri Y: Crab digestive lipase acting at high temperature: Purification and biochemical characterization. Biochimie 2007, 89:1012-1018.

30. Cherif S, Ben Bacha A, Ben Ali Y, Horchani H, Gargouri Y: Crab digestive phospholipase: A new invertebrate member Contents lists. Bioresource Technol 2010, 101:366-371.

31. Elpidina EN, Tsybina TA, Dunaevsky YE, Belozersky MA, Zhuzhikov DP, Oppert B: A chymotrypsin-like proteinase from the midgut of Tenebrio molitor larvae. Biochimie 2005, 87:771-779.

32. Herreroa S, Combes E, Van Oers MM, Vlak JM, Maagda RA, Beekwilder J: identification and recombinant expression of a novel chymotrypsin from Spodoptera exigua. Insect Biochem Mol Biol 2005, 35:1073-1082.

doi:10.1186/1476-511X-10-121

Cite this article as: Louati et al: A new chymotrypsin-like serine protease involved in dietary protein digestion in a primitive animal, Scorpio maurus: purification and biochemical characterization. Lipids in Health and Disease 2011 10:121.

\section{Submit your next manuscript to BioMed Central and take full advantage of:}

- Convenient online submission

- Thorough peer review

- No space constraints or color figure charges

- Immediate publication on acceptance

- Inclusion in PubMed, CAS, Scopus and Google Scholar

- Research which is freely available for redistribution

Submit your manuscript at www.biomedcentral.com/submit
C Biomed Central 